\title{
Role and mechanism of Glut-1 and H+/K+-ATPase expression in pepsin-induced development of vocal cord leukoplakia
}

\author{
Yin-Jie Ao ${ }^{1} \cdot$ Ting-Ting Wu$^{1} \cdot$ Zai-Zai Cao $^{1} \cdot$ Shui-Hong Zhou ${ }^{1}$ - $\cdot$ Yang-Yang Bao ${ }^{1} \cdot$ Li-Fang Shen $^{1}$
}

Received: 7 September 2021 / Accepted: 2 November 2021 / Published online: 20 November 2021

(c) The Author(s) 2021

\begin{abstract}
Purpose We investigated the role of Glut- 1 and $\mathrm{H}^{+} / \mathrm{K}^{+}$-ATPase expression in pepsin-induced development of human vocal cord leukoplakia cells (HVCLCs). Next, we analyzed the relationship between Glut- 1 and $\mathrm{H}^{+} / \mathrm{K}^{+}$-ATPase expression with the clinicopathological features of laryngeal carcinoma.

Methods Glut-1 and $\mathrm{H}^{+} / \mathrm{K}^{+}$-ATPase expression levels in HVCLCs were determined after treatment with artificial gastric juice containing pepsin and laryngeal carcinoma tissues.

Results Exposure to pepsin-containing artificial gastric juice significantly enhanced the migration and proliferation of VSCLCs in a time-dependent manner. The apoptotic rate of VSCLCs decreased over time after exposure to pepsin and reached a nadir on day $7(p<0.01)$. With increasing duration of exposure to pepsin, the proportion of VSCLCs in G0/G1 phase decreased and the proportions in the $\mathrm{S}$ and $\mathrm{G} 2 / \mathrm{M}$ phases significantly increased $(p<0.05)$. After treatment with pepsincontaining artificial gastric juice, RT-PCR and Western blotting showed that the expression of Glut- $1 \mathrm{and} \mathrm{H}^{+} / \mathrm{K}^{+}$-ATPase $\alpha$, $\beta$ significantly increased in HVCLCs compared to in the absence of pepsin $(p<0.05)$. The expression of Glut- 1 and $\mathrm{H}^{+} / \mathrm{K}^{+}-$ ATPase $\alpha, \beta$ gradually increased from vocal cord leukoplakia (VLC) to laryngeal carcinoma $(p<0.05)$. Lentivirus-mediated inhibition of Glut-1 expression in VCL significantly inhibited the cells' migration and proliferation $(p<0.05)$ but enhanced their apoptosis $(p<0.05)$. Also, inhibition of Glut-1 expression resulted in an increased proportion of cells in G0/G1 phase and a significantly decreased proportion in $\mathrm{G} 2 / \mathrm{M}$ phase $(p<0.05)$.

Conclusions Elevated Glut-1 expression may promote the development of VCL by upregulating laryngeal $\mathrm{H}^{+} / \mathrm{K}^{+}$-ATPase expression to reactivate absorbed pepsin, thus damaging the laryngeal mucosa.
\end{abstract}

Keywords Vocal cord leukoplakia $\cdot$ Precancerous lesion $\cdot$ Laryngopharyngeal reflux $\cdot$ Pepsin $\cdot$ Glut- $1 \cdot \mathrm{H}^{+} / \mathrm{K}^{+}$-ATPase

\section{Introduction}

Vocal cord leukoplakia (VCL), which is a clinical diagnosis with an underlying pathology characterized by various lesions (e.g., squamous hyperplasia with or without epithelial keratosis, as well as vocal cord mucosal dysplasia), is a common laryngeal precancerous lesion [1]. Its malignant transformation rate varies from 2 to $74 \%[2,3]$. The underlying etiologies of VCL are long-term smoking and alcohol abuse, inhaled irritant substances, and viral infection such as HPV [4]. Research has focused on the role of

Shui-Hong Zhou

1190051@zju.edu.cn

1 Department of Otolaryngology, The First Affiliated Hospital, College of Medicine, Zhejiang University, 79 Qingchun Road, Hangzhou City 310003, People's Republic of China laryngopharyngeal reflux (LPR) in the development of VCL. LPR refers to the reflux of gastric contents above the upper esophageal sphincter, which causes a series of symptoms and signs [5].

Gastric contents include gastric acid and non-acid components such as pepsin, cholate, bacteria, and trypsin [6]. VCL is associated with LPR $[1,4]$. Weakly acidic LPR plays an important role in the pathological changes seen in VCL. We reported high expression of pepsin in vocal cord polyp and VCL, and pepsin expression in VCL significantly increased according to the grade of dysplasia [1]. However, the role and mechanism of pepsin in the development of VCL are unclear.

Pepsin can be secreted by only the chief cells of the stomach. Pepsin may reach the larynx by adhering to laryngeal cell membranes, or through absorption by laryngeal epithelial cells via receptor-mediated endocytosis at $\mathrm{pH} 7$, followed 
by storage in vesicles and transport to intracellular vesicles such as Golgi bodies [7-9]. Pepsin under these conditions is stable but inactivated or dormant. Pepsin is reactivated by the reduction in the $\mathrm{pH}$ of the laryngeal microenvironment $[4,7-10]$. Tissue damage caused by pepsin activity may be mediated by the epithelial-mesenchymal transition (EMT), cellular mitochondria [11-13], oxidative DNA damage [14], and laryngeal mucosal protective proteins [15].

$\mathrm{H}+/ \mathrm{K}+$-ATPase proton pumps have been found in a number of extra-gastric tissues, including the larynx [16-23]. $\mathrm{H}+/ \mathrm{K}+$-ATPase was found in normal laryngeal tissues, and its expression was higher in laryngeal carcinoma [19]. The function of gastric $\mathrm{H}+/ \mathrm{K}+-$ ATPase is gastric acid secretion. It is speculated that extra-gastric $\mathrm{H}+/ \mathrm{K}+$-ATPase proton pumps also secrete acid. Therefore, we suggest that the acid secreted by $\mathrm{H}+/ \mathrm{K}+-$ ATPase in the larynx decreases the $\mathrm{pH}$, reactivating pepsin in the laryngeal mucosa and damaging laryngeal epithelial cells.

Chronic pepsin stimulation may result in further laryngeal epithelial damage and transformation of VCL, which is a long-term process involving multiple factors. Glucose metabolism involves a metabolic shift from oxidative phosphorylation (OXPHOS) to glycolysis [24, 25]. Glucose transporter-1 (Glut-1) is an important regulator of energy demand during the development of precancerous lesion cells $[26,27]$. High expression of Glut-1 enhanced glycolysis, increasing lactate 28 and reducing the microenvironment $\mathrm{pH}$. The decreased $\mathrm{pH}$ may reactivate pepsin. Therefore, we suggest that Glut-1 is key in pepsin-induced development of VCL.

To test the above hypotheses, we first investigated the expression and role of Glut- 1 and $\mathrm{H}^{+} / \mathrm{K}^{+}$-ATPase in the proliferation, growth, and development of human vocal cord leukoplakia cells (HVCLCs) in pepsin containing artificial gastric contents. Next, we verified the expression of Glut-1 and $\mathrm{H}^{+} / \mathrm{K}^{+}$-ATPase in VCL and laryngeal carcinoma tissues and analyzed the relationship between Glut- 1 and $\mathrm{H}^{+} / \mathrm{K}^{+}$ATPase expression with the clinicopathological features of laryngeal carcinoma.

\section{Materials and methods}

This study was approved by the institutional review board of The First Affiliated Hospital, College of Medicine, Zhejiang University, China (No. 201901022). All authors had access to the study data and reviewed and approved the final manuscript, and the study was conducted in compliance with the Declaration of Helsinki.

\section{Primary culture of HVCLCs}

\section{Clinical information}

A 68-year-old man presented with a 2-month history of sustained hoarseness, sore throat, and dysphagia. His medical history included 13 years of hypertension, which was controlled by Amlodipine. Suspension laryngoscopy showed that his bilateral vocal cords were covered by graywhite keratinized tissue. The pathological results (No. F201710918) confirmed the clinical diagnosis of leukoplakia of the vocal cords. Specifically, small pieces of squamous epithelium indicated hyperplasia, and the differentiation was good.

\section{Primary cell culture}

Fresh leukoplakia tissue obtained during surgery was rapidly transferred into cold double-anti-Dulbecco's modified Eagle's medium (DMEM)/F12, transported to the laboratory and processed immediately. The tissue block was rinsed three times with sterile D-Hank's solution and placed in a sterile vial. Next, $2.4 \mathrm{mg} / \mathrm{mL}$ Dispase II solution was added to digest the tissue. The tissue block was removed, and ophthalmic forceps were used to separate the epithelial tissue from the underlying connective tissue. The epithelial tissue was rinsed two or three times with D-Hank's solution.

\section{Cell harvesting}

Configured digestive solution $(0.25 \%$ trypsin and $0.02 \%$ ethylenediaminetetraacetic acid; $1: 1)$, was prewarmed in an incubator. Epithelial tissue was cut into small pieces $\left(0.5-1 \mathrm{~mm}^{3}\right)$, which were immersed in the digestive solution and incubated at $37{ }^{\circ} \mathrm{C}$ for $20 \mathrm{~min}$. After centrifugation (1000 rpm, $5 \mathrm{~min}$ ), the supernatant was discarded, and the tissue was washed three times in Hank's solution. The process was repeated twice. The cells were suspended in complete medium and passed through a $100-\mu \mathrm{m}$-mesh filter. The remaining cells were suspended in DMEM with $1 \%$ penicillin/streptomycin and $10 \%$ fetal bovine serum. A $25-\mathrm{cm}^{3}$ disposable culture flask was seeded with $5 \times 10^{5}$ cells and incubated for $1 \mathrm{~h}$ at $37{ }^{\circ} \mathrm{C}$ in a humidified atmosphere containing $5 \% \mathrm{CO}_{2}$. The medium was changed every 2 days and the condition of the cells was observed daily under a phase-contrast microscope.

\section{Cell Counting Kit-8 assay}

Cell Counting Kit-8 (CCK-8) solution $(50 \mu \mathrm{L})$ was added to the dishes and cultured for $4 \mathrm{~h}$ at $37{ }^{\circ} \mathrm{C}$. Pipetted $100 \mu \mathrm{L}$ 
per well and transferred them to specific 96-well plate. The absorbance at $450 \mathrm{~nm}$ was determined using an enzymelinked immunosorbent assay reader.

\section{Immunofluorescence of vimentin, CEA, and keratin}

Supernatant was aspirated and the dishes were washed twice with phosphate-buffered saline (PBS). Cells in the experimental groups were fixed in $4 \%$ paraformaldehyde at $4{ }^{\circ} \mathrm{C}$ overnight, washed in PBS three times for 5 min each, and incubated with $0.5 \%$ Triton X-100 (in PBS) for $10 \mathrm{~min}$. Next, the cells were washed in PBS for 5 min, blocked with $1 \%$ bovine serum albumin for $30 \mathrm{~min}$, and cultured in the indicated 1:50-diluted primary antibody solution at $4{ }^{\circ} \mathrm{C}$ overnight. The cells were washed in PBS three times for $5 \mathrm{~min}$ each and cultured in diluted secondary antibody solution at $37^{\circ} \mathrm{C}$ for $2 \mathrm{~h}$. The cells were washed in PBS three times for 5 min each and stained with 4',6-diamidino-2-phenylindole for $3 \mathrm{~min}$. Finally, the cells were washed in PBS three times for $5 \mathrm{~min}$ each, sealed in 50\% glycerol, and visualized and photographed by laser confocal microscopy.

\section{Three-dimensional culture of HVCLCs, laryngeal carcinoma Tu2 12 cells and AMC-HN-8 cells}

Leukoplakia epithelial cells, laryngeal carcinoma Tu212 cells (Icell Bioscience, Shanghai, China), and AMC-HN-8 cells (BnBio, Beijing, China) were suspended at $1 \times 10^{8}$ cells $/ \mathrm{mL}$. Matrigel was stored at $-20{ }^{\circ} \mathrm{C}$, thawed at $4{ }^{\circ} \mathrm{C}$ for 1 day, and $1 \mathrm{~mL}$ was placed on ice. Matrigel $(1 \mathrm{~mL})$ was mixed with $1 \mathrm{~mL}$ of DMEM, and $1 \mathrm{~mL}$ of cell suspension was mixed with $2 \mathrm{~mL}$ of Matrigel-DMEM. The above processes were carried out on ice. The cell suspension $(0.6 \mathrm{~mL})$ was added to five wells of a 24-well plate, which was transferred to a $37^{\circ} \mathrm{C}$ cell-culture incubator for $12 \mathrm{~h}$. Next, $1 \mathrm{~mL}$ of DMEM was added to each well and the plate was returned to the incubator. The upper liquid medium was replaced every other day, and cell growth was monitored daily under a light microscope.

\section{Exposure of HVCLCs to artificial gastric juice}

Artificial gastric juice (Soleibao, Beijing, China) comprised $8.2 \mathrm{~mL}$ of $9.5-10.5 \% \mathrm{HCL}+400 \mathrm{~mL}$ diluted $0.03 \mathrm{~mol} / \mathrm{L}$ $\mathrm{NaCl}$, to which was added $5 \mathrm{~g}$ pepsin; the final concentration was $0.01 \mathrm{~g} / \mathrm{mL}, \mathrm{pH} 2$. The experimental groups were: Group 1, HVCLCs without artificial gastric juice treatment (twodimensional [2D] 0, three-dimensional [3D] 0, respectively). Group 2, artificial gastric juice treatment for HVCLCs for 3 consecutive days (2D 3, 3D 3). Group 3, artificial gastric juice treatment for HVCLCs for 5 consecutive days (2D 5, 3D 5). Group 4, artificial gastric juice treatment for HVCLCs for 7 consecutive days (2D 7, 3D 7). Artificial gastric juice $(1500 \mu \mathrm{L})$ was added once a day.

\section{Transfection of HVCLCs with Glut-1 low-expressing lentivirus}

HVCLCs were transfected with Glut-1 low-expressing lentivirus (HanBio, Shanghai, China). Briefly, 1 day before virus transfection, a certain number of cells were transferred to a culture dish. When cells reached about $50 \%$ confluence, they were transfected. The cells were placed in a $37^{\circ} \mathrm{C}$ incubator for $20 \mathrm{~h}$. The virus was dissolved in an ice bath and pipetted gently for mixing. The lentivirus titer was $1 \times 10^{8} \mathrm{TU} /$ $\mathrm{mL}$, and the MOI was 15 . The primary culture medium was aspirated, virus-containing culture medium was added, and the dish shaken to ensure that medium covered the cells. The cells were incubated at $37{ }^{\circ} \mathrm{C}$ overnight. One day after transfection, the virus-containing medium was discarded, and fresh DMEM was added. The cells were incubated at $37{ }^{\circ} \mathrm{C}$. The success of viral transfection was determined by fluorescence excitation. When the virus transfection rate reached about $80 \%$, antibiotics were added to screen the cells. Finally, the cells were divided into three groups: HVCLCs transfected with Glut-1 low-expressing lentivirus, HVCLCs and HVCLCs carries only the fluorescent framework were used as controls.

\section{Transwell assay}

Cells were digested with trypsin, centrifuged, and enumerated. The cell density was adjusted to $5 \times 10^{5} / \mathrm{mL}$. Matrigel was diluted with DMEM at a ratio of 8:1. Diluted Matrigel (40 $\mu \mathrm{L}$ ) was added to the Transwell chamber and cell suspension $(150 \mu \mathrm{L})$ was added to the Transwell compartment. DMEM $(800 \mu \mathrm{L})$ containing $20 \%$ FBS was added to the lower chamber. The Transwell chamber was removed, and the culture medium in the six-well plate was discarded. The Transwell chamber was washed with PBS, fixed in $4 \%$ formaldehyde for $20 \mathrm{~min}$, washed with PBS for $5 \mathrm{~min}$, and stained with $0.1 \%$ crystal violet for $30 \mathrm{~min}$. The upper layer of unmigrated cells was removed with cotton swabs, and the Matrigel was removed. The cells were enumerated and photographed. Each experiment was performed in triplicate.

\section{Wound-healing assay}

A two-well cell-scratch module was used to ensure a scratch width of $500 \mu \mathrm{m}$. The module was placed in a 24 -well plate and $70 \mu \mathrm{L}$ of a cell suspension $\left(5 \times 10^{5} / \mathrm{mL}\right)$ were added to both sides of the module. After $6 \mathrm{~h}$, the cells were confirmed to be completely attached to the wall. Sterile forceps were used to remove the module, and $1 \mathrm{~mL}$ of culture medium was 
added along the plate wall. Finally, healing of the scratches was monitored visually.

\section{CCK-8 assay}

Cell suspension $(100 \mu \mathrm{L})$ was added to a $96-w e l l$ plate and $100 \mu \mathrm{L}$ of DMEM was added to each well. Next, $10 \mu \mathrm{L}$ of CCK- 8 was added to each well. The cells were incubated at $37{ }^{\circ} \mathrm{C}$ for $2 \mathrm{~h}$. The absorbance of each well at $450 \mathrm{~nm}$ was determined using the Spectra Plus Microplate Reader (Molecular Devices, Sunnyvale, CA).

\section{Flow cytometry}

After digestion, cell suspension was dripped into a centrifuge tube containing anhydrous alcohol and PBS (3:1) and fixed for $24 \mathrm{~h}$. The cells were next washed with PBS, transferred to a tube, centrifuged (1000 rpm, $5 \mathrm{~min}$ ), and the supernatant discarded. Cell-cycle-staining buffer was added, and the tube was placed in the dark for $30 \mathrm{~min}$. Cells $\left(5 \times 10^{5}\right)$ were collected and centrifuged (1000 rpm, $\left.5 \mathrm{~min}\right)$. The medium was discarded, the cells were washed with $3 \mathrm{~mL}$ of PBS, passed through a 400-mesh filter, and centrifuged (1000 rpm, $5 \mathrm{~min})$. Next, the cells were placed in the dark at $4{ }^{\circ} \mathrm{C}$ for $30 \mathrm{~min}$ and the proportions undergoing non-apoptotic programmed cell death and apoptosis, and the proportions in the various stages of the cell cycle, were evaluated by flow cytometry in triplicate and analyzed by CytExpert software (Beckman Coulter, Inc., CA).

\section{Patients and tissue samples}

We analyzed 30 pathological specimens from patients with laryngeal carcinoma, 30 from patients with VCL, and 30 samples of paracarcinoma tissue (taken $0.5 \mathrm{~cm}$ from the negative margin after tumor excision) from patients with laryngeal carcinoma treated at our hospital between November 2014 and July 2020. The inclusion criteria were: for the leukoplakia group, a confirmed pathological diagnosis of squamous epithelial hyperplasia or mild, moderate, or severe atypical hyperplasia; for the laryngeal carcinoma group, a confirmed pathological diagnosis of squamous cell carcinoma. Exclusion criteria were preoperative radiotherapy and/or chemotherapy and/or immunotherapy; treatment with PPIs; coexisting metabolic or autoimmune diseases; incomplete medical records; and/or loss to follow-up.

\section{Quantitative real-time RT-PCR}

Total RNA was isolated according to the manufacturer's instructions. Briefly, $1 \mu \mathrm{g}$ of RNA was reverse-transcribed using a First-Strand cDNA Kit (EZB-RT2GQ SYBR ON) and subjected to PCR using a SYBR Green qPCR Kit
(A0001-R2 SYBR ON), incubated at $42^{\circ} \mathrm{C}$ for $15 \mathrm{~min}$, and stored at $-20{ }^{\circ} \mathrm{C}$. RNA primers were designed and synthesized by Sangon. The primers for Glut-1 (Abcam, Cambridge, UK) were forward 5'-GGTCATGAGTATGGCACA ACC-3' and reverse 5'-GTCAACACGGCCTTCAC-3'. The primers for $\mathrm{H}^{+} / \mathrm{K}^{+}$-ATPase $\alpha$ (Abcam) were forward 5'-CAT CATCGCCAGCTTTAAGAAC-3' and reverse 5'-CAG CGTTGATCTGGAATTTGTC-3'. The primers for $\mathrm{H}^{+} / \mathrm{K}^{+}$ATPase $\beta$ (Abcam, Cambridge, UK) were forward 5'-CAG TCTGCACTACTTCCCTTAT-3' and reverse 5'-CACTTT CCCTTCATACGGGTC-3'. The primers for anti-glyceraldehyde 3-phosphate dehydrogenase (GAPDH) (CST, Boston, MA) were forward 5'-GAAGGTGAAGGTCGGAGT C-3' and reverse 5'-GAAGATGGTGATGGGATTTC-3'. The PCR products were 111 bp (Glut-1), 80 bp ( $\alpha$-subunit), $175 \mathrm{bp}(\beta$-subunit) and $172 \mathrm{bp}(\mathrm{GAPDH})$ in length. The $2^{\Delta \Delta \mathrm{Ct}}$ method was used to calculate relative gene expression levels. The experiments were performed in triplicate.

\section{Western blotting}

Western blotting was performed in accordance with the manufacturer's instructions. Rabbit monoclonal anti-Glut-1 $(1: 1000),-\mathrm{H}^{+} / \mathrm{K}^{+}$-ATPase $\alpha(1: 2,000)$, and $-\mathrm{H}^{+} / \mathrm{K}^{+}$ATPase $\beta(1: 1,000)$ were purchased from Abcam (Cambridge, UK), and GAPDH $(1: 1,000)$ from CST (Boston, MA). The secondary antibodies were goat anti-rabbit antibodies $(1: 1,000)$ conjugated with horseradish peroxidase (Abcam). Signals were visualized using ImageJ software (National Institutes of Health, Bethesda, MD). Protein levels were quantified by scanning densitometry in triplicate.

\section{Immunohistochemistry}

Paraffin sections were cut at $5 \mu \mathrm{m}$ thickness. After deparaffinization and hydration, the sections underwent antigen retrieval by the microwave-oven method. Endogenous peroxidase activity was blocked in $3 \% \mathrm{H}_{2} \mathrm{O}_{2}$ for $25 \mathrm{~min}$ at room temperature. Next, the slides were incubated with primary antibodies against Glut-1 (1:200), $\mathrm{H}^{+} / \mathrm{K}^{+}$-ATPase $\alpha$ (1:200), and $\mathrm{H}^{+} / \mathrm{K}^{+}$-ATPase $\beta$ (1:200) overnight. The next day, the sections were incubated with the corresponding secondary antibodies (1:200) at room temperature for $50 \mathrm{~min}$, stained using a DAB Staining Kit and subjected to hematoxylinand-eosin staining. The sections were photographed under a microscope; cells labeled with brownish-yellow granules were considered positive. Five high-magnification fields $(\times 400)$ were randomly selected, in each of which 100 cells were counted; scoring was as follows: $0 ; 1,<25 \% ; 2$, $26-50 \%$; and $3, \geq 50 \%$ positive cells. Dye depth was scored as follows: 0 , no staining; 1 , light yellow; 2 , brownish-yellow; and 3, deep brownish-yellow. Immunohistochemical data were assessed as the positive-cell score + the dye-depth 
score. Total scores of $0-1,2,3-4$, and 5-6 were considered negative $(-)$, weakly positive $(+)$, positive $(++)$, and strongly positive $(+++)$, respectively. The investigator was blinded to the group allocation.

\section{Statistical analysis}

Associations of Glut- 1 and $\mathrm{H}^{+} / \mathrm{K}^{+}$-ATPase expression with clinicopathological parameters were assessed by the chi-squared test or Fisher exact test. Continuous data are expressed as means \pm standard deviations and were analyzed by dependent $t$-test for within-subject differences. A Pearson correlation analysis was conducted. $P$-values $<0.05$ were indicative of statistical significance. GraphPad Prism 7 software was used for graphing and statistical analysis was performed using SPSS Statistics for Windows (ver. 19.0; IBM Corp., Armonk, NY).

\section{Results}

\section{Role of Glut-1 and $\mathrm{H}+/ \mathrm{K}+-$ ATPase $\alpha, \beta$ in pepsin-induced development of vocal cord leukoplakia}

\section{Two- and three-dimensional culture of primary vocal cord leukoplakia cells}

VCL cells grew densely at the bottom of the culture dish. The cells were spindle-shaped and closely packed, reminiscent of paving stones. The cells were fused, elongated, transparent, and rich in cytoplasm, and the nucleus was located at the center. On day 7 after passage, their growth state was good, and the cells were passaged daily thereafter (Fig. 1a). The cells ceased proliferating after 5 days; the mean doubling time was $2-3$ days (Fig. 1b). To identify leukoplakia epithelial cells, we performed immunofluorescence for CEA and CK-8, markers of leukoplakia epithelial cells. Of the cells, $>90 \%$ were positive for CEA and CK- 8 but $<5 \%$ were positive for vimentin, in 2D culture (Fig. 1c). These characteristics are in accordance with those of leukoplakia epithelial cells.

By comparison, fewer spindle-shaped cells were observed in $3 \mathrm{D}$ culture. In addition, leukoplakia epithelial cells were stratified and distributed mainly at the gel-liquid interface. On day 3, mature leukoplakia epithelial cells of typical paving-stone arrangement were observed. Cell clusters started to appear, with ever-increasing $3 \mathrm{D}$ profiles. On day 6 , large cell clusters were interconnected by pseudopods. On day 9 , Matrigel was occupied by cells (Fig. 1d). On day 1, several spindle-shaped laryngeal carcinoma Tu212 and AMC-HN-8 cells were observed, and several small colonies were evident on day 3. On day 6 , a number of spindle-cell colonies were present and on day 9, many cell colonies were visible (Fig. 1e, f).

\section{Pepsin modulates the migration, proliferation, apoptosis, and cell-cycle distribution of VSCLCs}

Exposure to pepsin-containing artificial gastric juice significantly enhanced the migration and proliferation of VSCLCs in a time-dependent manner ( $\mathrm{p}<0.05$, Fig. $2 \mathrm{a}-\mathrm{c})$, with a peak on day 5. However, the migration of VSCLCs was less obvious than that of laryngeal carcinoma AMC-HN-8 cells and TU212 cells $(p<0.05$; Fig. 3a-c). The apoptotic rate of VSCLCs was higher than that of laryngeal carcinoma AMCHN-8 cells and TU212 cells ( $p<0.05$, Fig. 3 d). The apoptotic rate of VSCLCs decreased over time after exposure to pepsin and reached a nadir on day 7 ( $p<0.01$, Fig. 2d). The proportion of VSCLCs in S phase was significantly increased compared to laryngeal carcinoma AMC-HN-8 cells and TU212 cells ( $p<0.05$, Fig. 3e). With increasing duration of exposure to pepsin, the proportion of VSCLCs in $\mathrm{G} 0 / \mathrm{G} 1$ phase decreased and the proportions in the $\mathrm{S}$ and $\mathrm{G} 2 / \mathrm{M}$ phases significantly increased ( $p<0.05$, Fig. 2e). Therefore, pepsin promoted the migration, and proliferation of VSCLCs, but inhibited their apoptosis.

Lentivirus-mediated inhibition of Glut- 1 expression in VCL significantly inhibited the cells' migration and proliferation $(p<0.05)$ but enhanced their apoptosis $(p<0.05)$. Also, inhibition of Glut-1 expression resulted in an increased proportion of cells in $\mathrm{G} 0 / \mathrm{G} 1$ phase and a significantly decreased proportion in G2/M phase ( $p<0.05$, Fig. 4 ).

\section{Glut-1 and $H^{+} / K^{+}$-ATPase $\alpha, \beta$ expression}

In $2 \mathrm{D}$ and $3 \mathrm{D}$ models, Glut- 1 and $\mathrm{H}^{+} / \mathrm{K}^{+}$-ATPase $\alpha, \beta$ expression was significantly lower in VCL cells than in Tu212 laryngeal carcinoma cells and AMC-HN-8 cells $(p<0.05$, Figure.S1). Also, Glut- 1 and $\mathrm{H}^{+} / \mathrm{K}^{+}$-ATPase $\alpha, \beta$ expression in VCL, Tu212 laryngeal carcinoma cells and AMC-HN-8 cells was positively correlated. Therefore, Glut-1 modulates the physiological characteristics of cells in precancerous lesions.

In 2D and 3D models of VCL, pepsin-containing artificial gastric juice significantly increased Glut- 1 and $\mathrm{H}^{+}$/ $\mathrm{K}^{+}$-ATPase $\alpha, \beta$ expression compared to that in the absence of pepsin ( $p<0.05$, Fig. 5).

Inhibition of Glut-1 expression in VCL significantly decreased Glut- 1 and $\mathrm{H}^{+} / \mathrm{K}^{+}$-ATPase $\alpha, \beta$ expression compared to both control groups ( $p<0.01$, Figure.S2). Moreover, Glut-1 expression was positively correlated with that of $\mathrm{H}^{+} / \mathrm{K}^{+}$-ATPase $\alpha, \beta$. Western blotting showed that Glut-1 low-expression lentivirus inhibited the expression of Glut-1 protein only after transfection $(p<0.01$, Figure. S2), albeit not significantly. Therefore, transfection with 


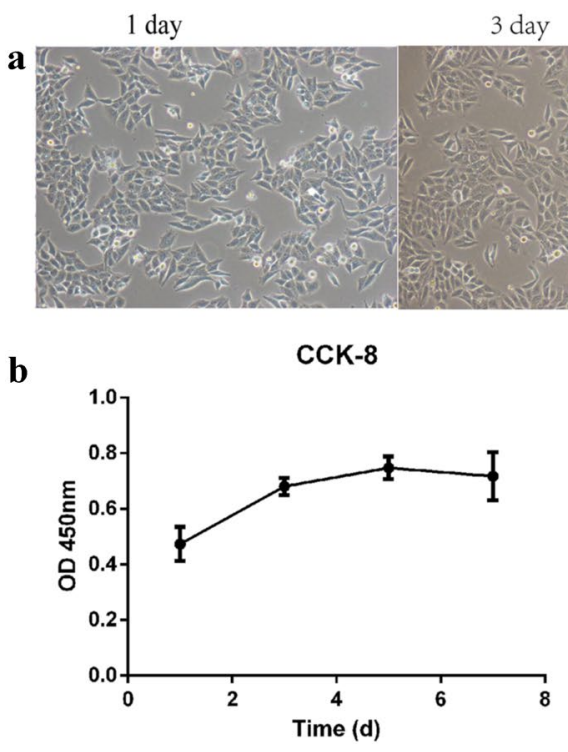
5 day
7 day

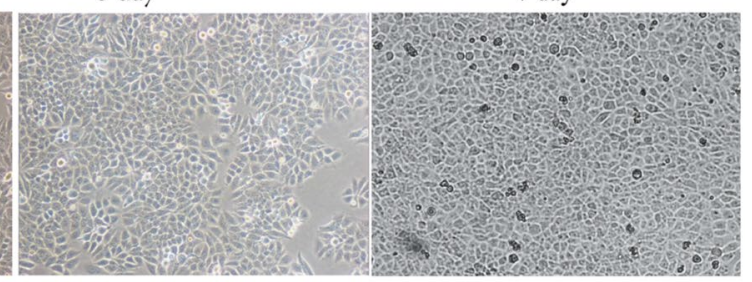

c
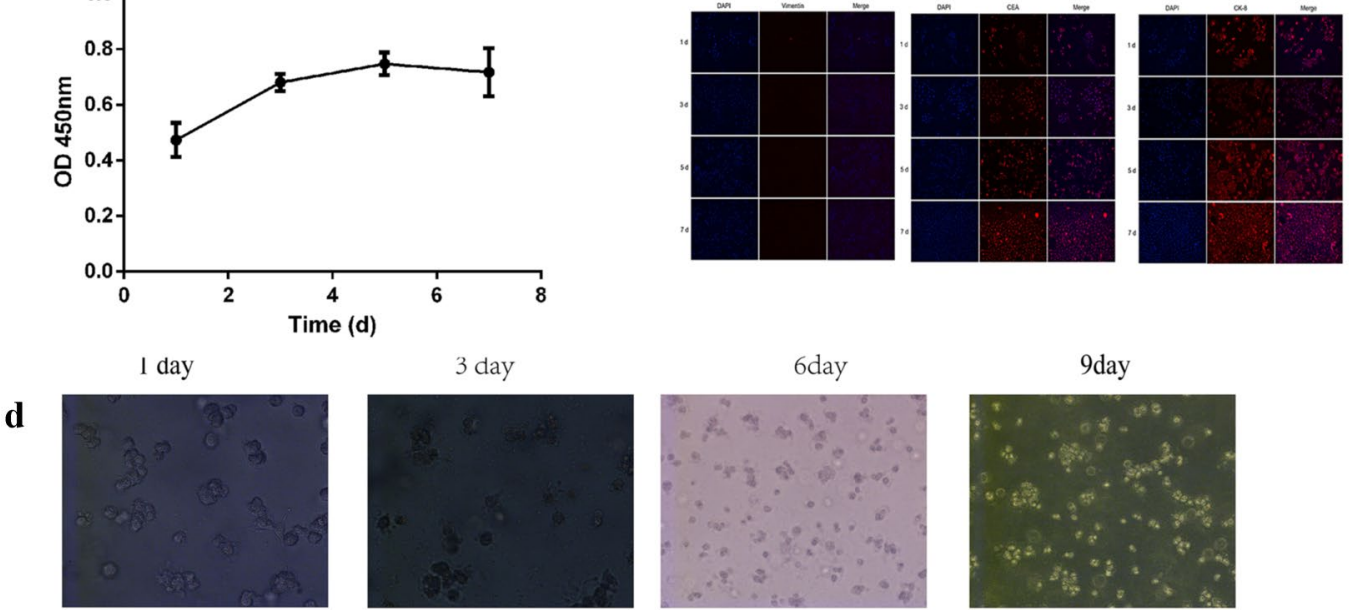

e
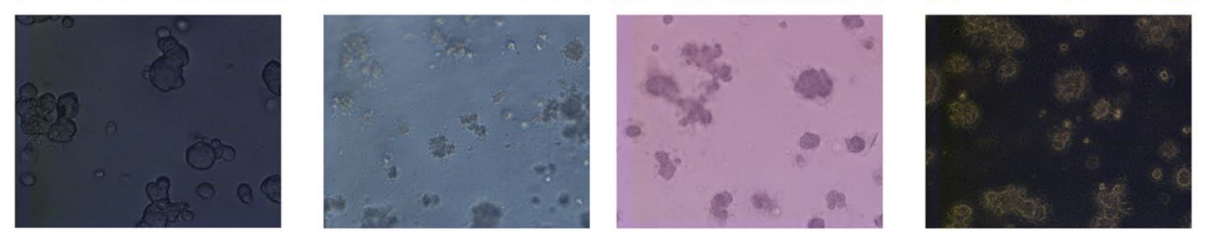

f

1 day

3 day

5 day
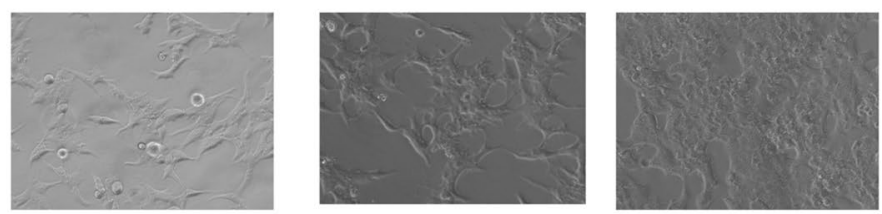

9day

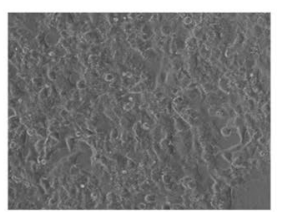

Fig. 1 Culture of VCL cells in 2D and 3D. a Morphology of thirdgeneration HVCLCs 2D cultured for 1, 3, 5, and 7 days. b CCK-8 assay. $\mathbf{c}$ Expression of vimentin, CEA, and CK-8 by immunofluores-

Glut-1 low-expressing lentivirus affected $\mathrm{H}^{+} / \mathrm{K}^{+}$-ATPase $\alpha$, $\beta$ expression only at the transcriptional level.

\section{Glut-1 and $\mathrm{H}^{+} / \mathrm{K}^{+}$-ATPase $\boldsymbol{\alpha}, \boldsymbol{\beta}$ expression in laryngeal carcinoma and vocal cord leukoplakia tissues}

Glut- 1 and $\mathrm{H}^{+} / \mathrm{K}^{+}$-ATPase $\alpha, \beta$ expression in laryngeal carcinoma tissues was higher than that in leukoplakia tissues $(p<0.05$, Fig. S3a), which was higher than their expression in paracancerous tissue ( $p<0.05$, Fig. S3). IHC showed a similar tendency; however, only Glut-1 expression differed significantly between laryngeal carcinoma and leukoplakia cence. d 3D culture of HVCLCs for 1, 3, 6, and 9 days. 3D model of (e) laryngeal carcinoma Tu212 cells and (f) AMC-HN-8 laryngeal carcinoma cells

tissues, and between leukoplakia tissues and paracancerous tissues $(p<0.05$, Fig.S3).

\section{Associations of Glut- 1 and $\mathrm{H}^{+} / \mathrm{K}^{+}$-ATPase $\alpha, \beta$ expression with clinicopathological features}

Glut-1 expression was significantly higher in early stage $\left(\mathrm{T}_{1}+\mathrm{T}_{2}\right)$ than in advanced stage $\left(\mathrm{T}_{3}+\mathrm{T}_{4}\right)$ laryngeal carcinoma $(p<0.05)$. Also, expression of $\mathrm{H}^{+} / \mathrm{K}^{+}$-ATPase $\beta$ was lower in well-differentiated laryngeal carcinoma than in moderately differentiated laryngeal carcinoma $(p<0.05)$. IHC showed that in patients with leukoplakia, $\mathrm{H}^{+} / \mathrm{K}^{+}$-ATPase $\alpha$ and $\beta$ expression were higher 
a

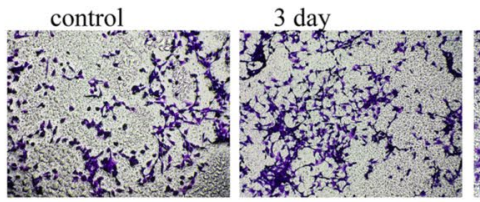

b

Oh

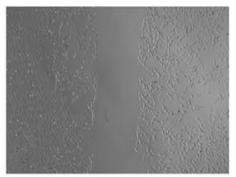

$24 \mathrm{~h}$

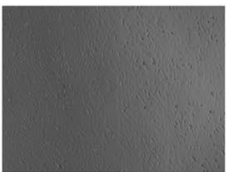

$48 \mathrm{~h}$
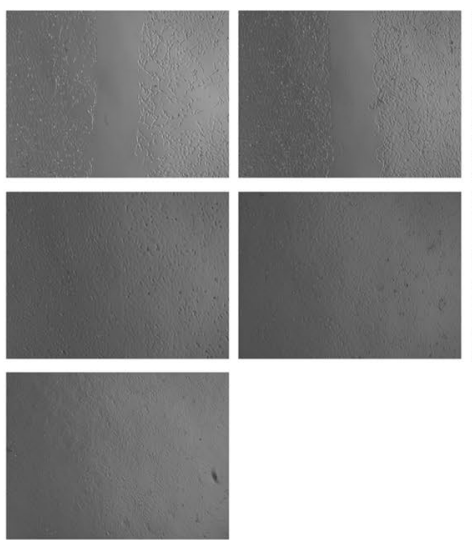

5 day

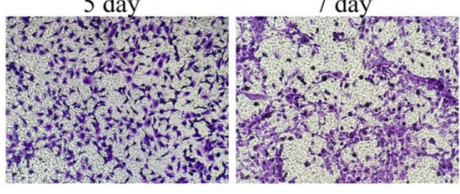

${ }_{200}^{800}$ $0^{0^{2}}$
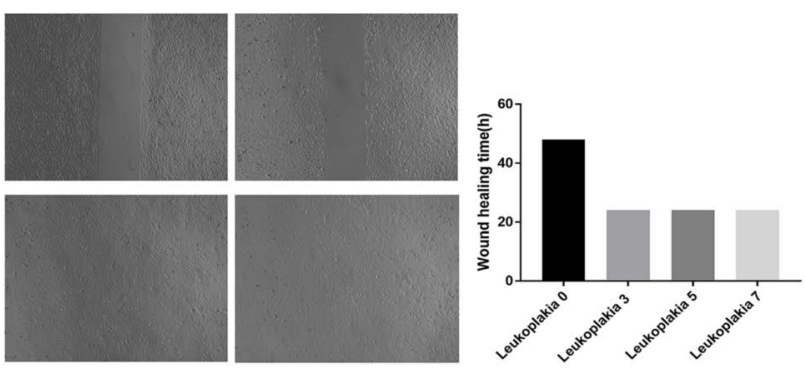

- Loukoplakia 5

$=$ Leukoplakia 7
- Leukoplakia o

Leukoplakia 3

- Leukoplakia 5

c

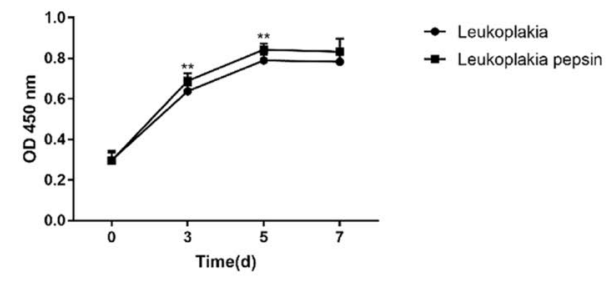

d
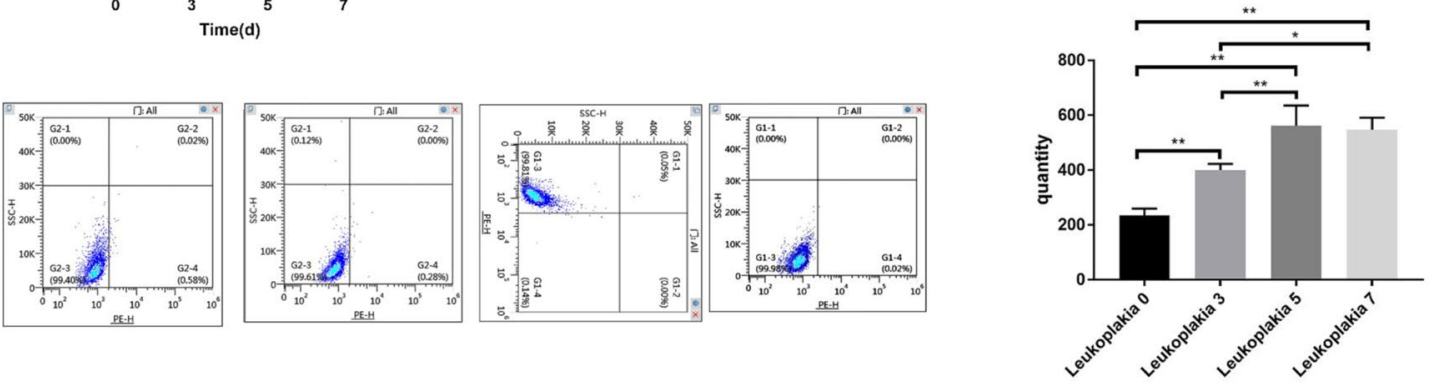

- Leukoplakia 0

- Leukoplakia 3

- Leukoplakia 5

- Leukoplakia 7

$\mathbf{e}$
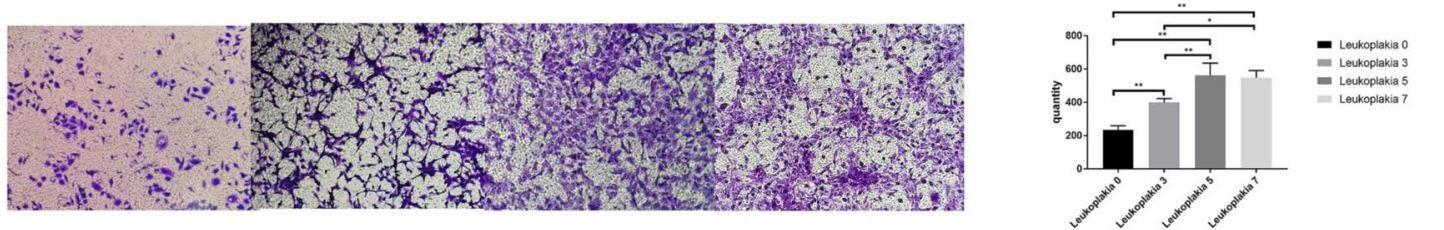

Fig. 2 Migration, proliferation, apoptosis, and cell-cycle distribution of HVCLCs exposed to pepsin-containing artificial gastric juice. a Transwell assay; b wound-healing assay; c CCK-8 assay; $\mathbf{d}$ apoptosis; e cell-cycle distribution

in those $\geq 60$ years old than in those $<60$ years old $(p<0.05)$. There was no significant correlation between Glut- 1 and $\mathrm{H}^{+} / \mathrm{K}^{+}$-ATPase $\alpha, \beta$ expression with any other clinicopathological feature of patients with laryngeal carcinoma or leukoplakia.

\section{Discussion}

Glut-1 modulates the Warburg effect by regulating glucose uptake into tumor tissues. We have reported that 


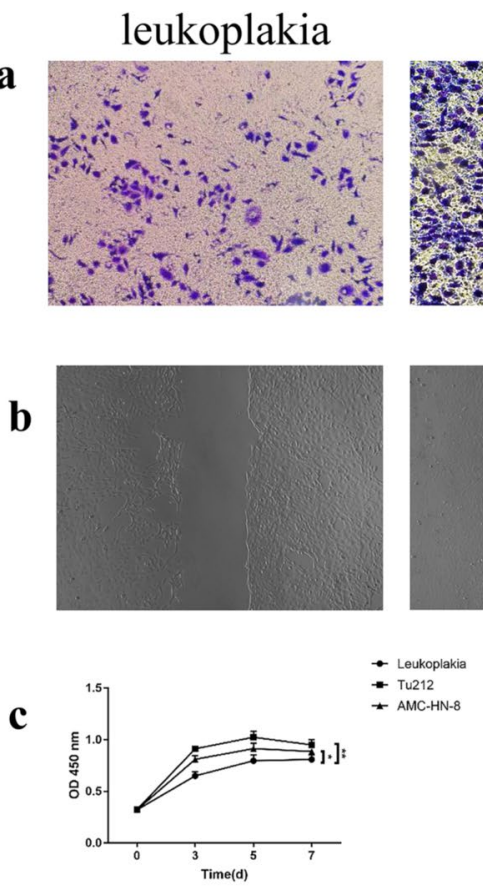

\section{AMC-HN-8}
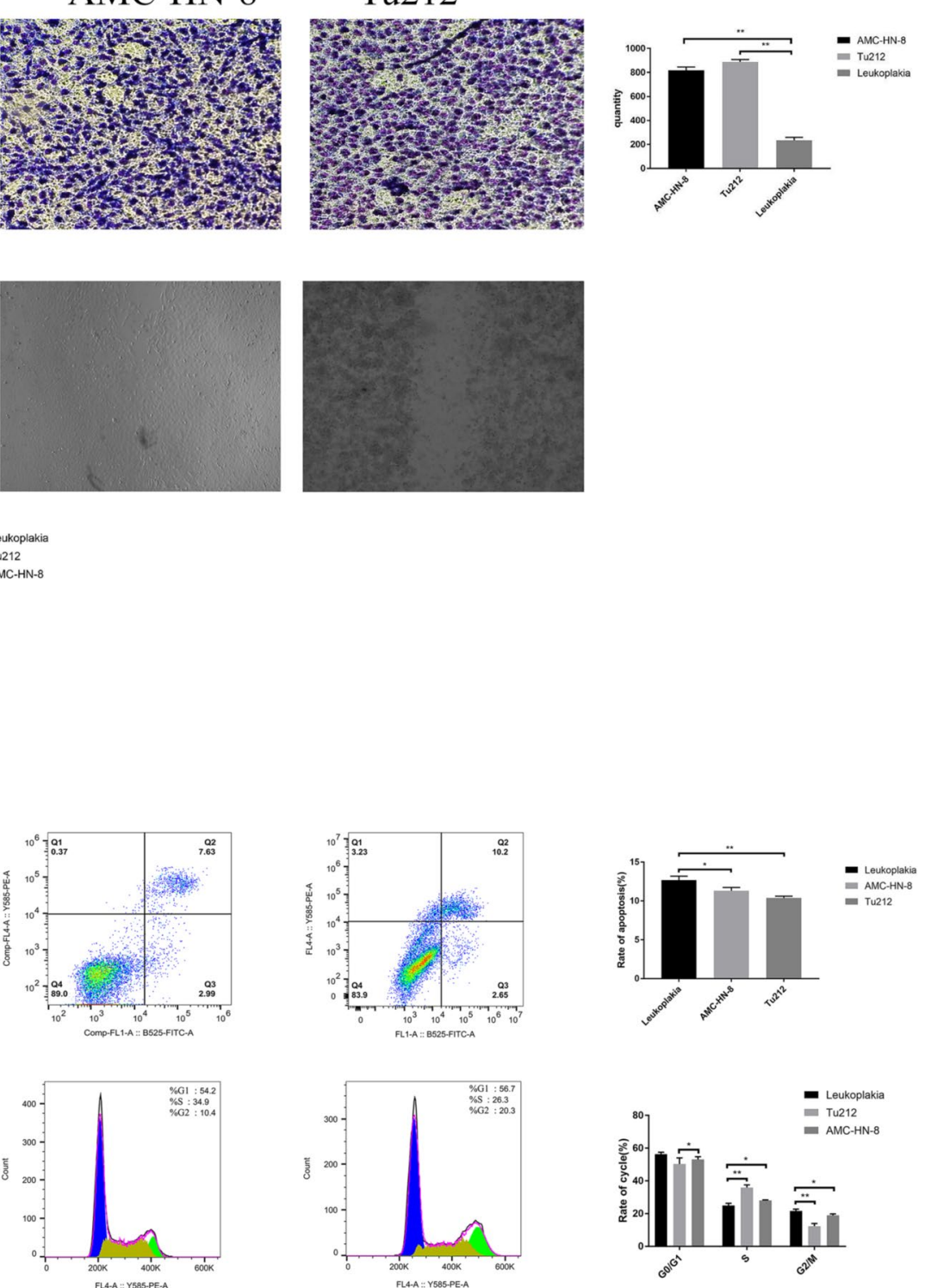

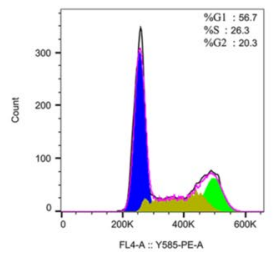

Fig. 3 Compare to laryngeal carcinoma cells, migration, proliferation, apoptosis, and cell-cycle distribution of HVCLCs exposed to pepsin-containing artificial gastric juice. a Transwell assay; $\mathbf{b}$ wound-healing assay; $\mathbf{c}$ CCK-8 assay; $\mathbf{d}$ apoptosis; e cell-cycle distribution

expression of Glut-1 in laryngeal carcinoma is elevated [27] and was associated with the proliferation and radioresistance of laryngeal carcinoma cells; targeted inhibition of Glut-1 expression suppressed their proliferation and radioresistance [26-28]. Although expression of Glut-1 was lower in HVCLCs than in laryngeal carcinoma Tu212 and AMC-HN-8 cells, we detected Glut- 1 expression in laryngeal precancerous lesions. The expression level of Glut-1 was associated with the migration, proliferation, apoptosis, and cell-cycle distribution of HVCLCs. Inhibition of Glut-1 expression decreased the migration and proliferation, and increased the apoptosis, of HVCLCs, as well as increasing the proportion in G0/G1 phase and decreasing that in G2/M phase. Therefore, Glut-1 alters the physiological properties of cells of laryngeal precancerous lesions. Others have shown that Glut-1 expression is upregulated in premalignant lesions (endometrial hyperplasia, premalignant lesions of the gallbladder, and oral leukoplakia and epithelial dysplasia) [29-32].

The mechanisms underlying the formation and development of VCL are unclear. LPR is associated with laryngeal precancerous lesions $[5,10]$, and pepsin is implicated in their development. We have reported that $68.0 \%$ of 45 pathologic specimens from patients with VCL were positive for pepsin, and pepsin expression increased as the grade of dysplasia of VCL increased $1 . \mathrm{H}+/ \mathrm{K}+$-ATPases are expressed in the 


\section{leukoplakia}

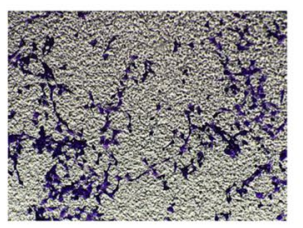

$24 \mathrm{~h}$

b

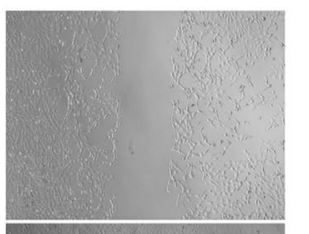

$48 \mathrm{~h}$
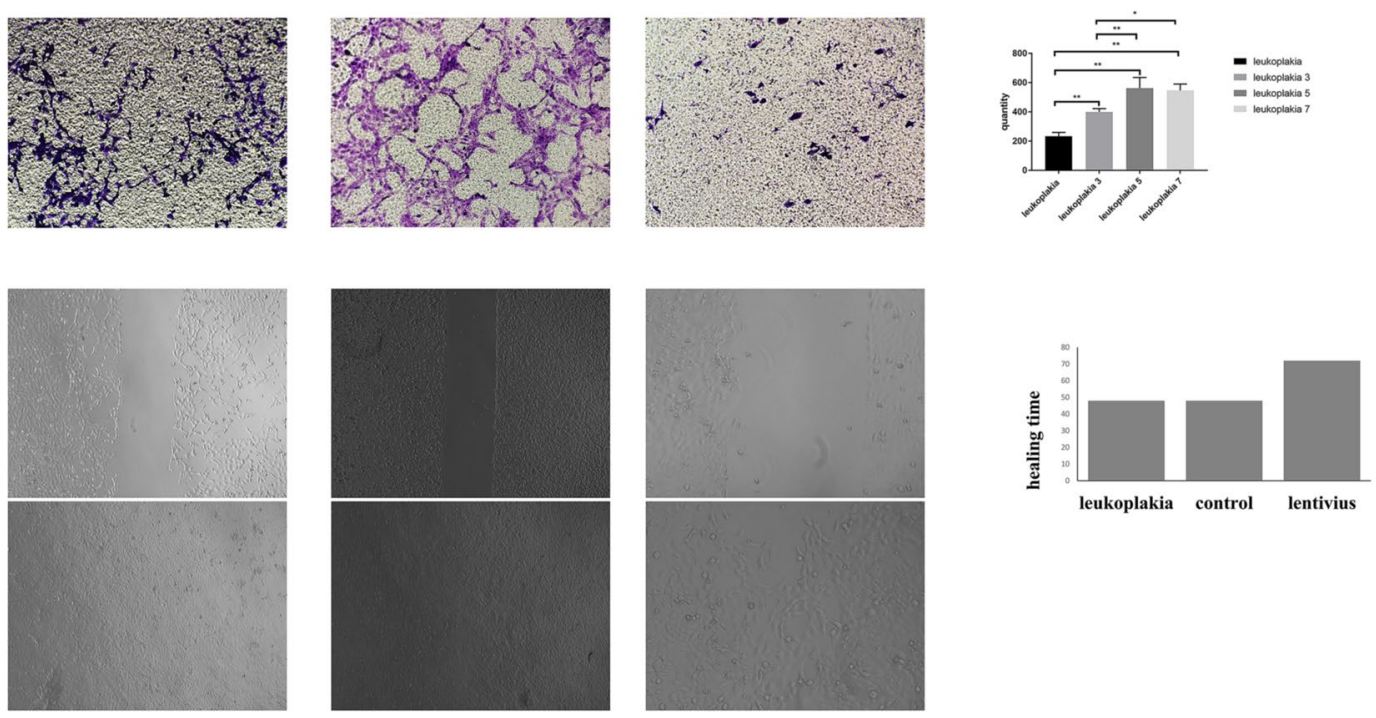

$72 \mathrm{~h}$

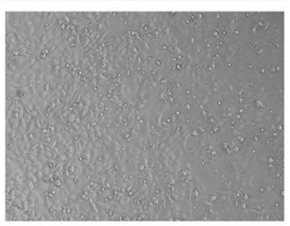

c

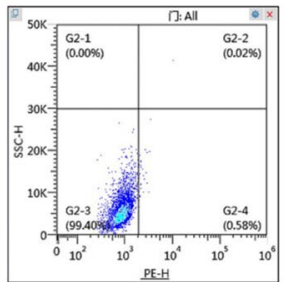

d

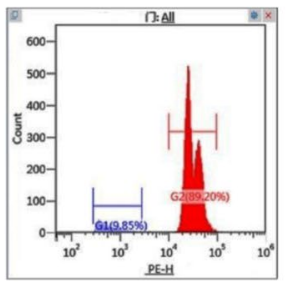

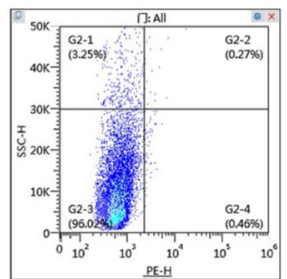

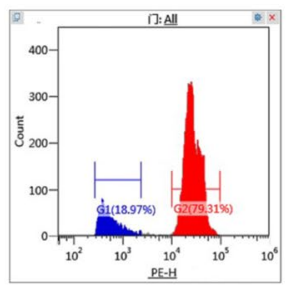

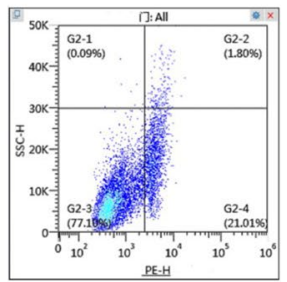
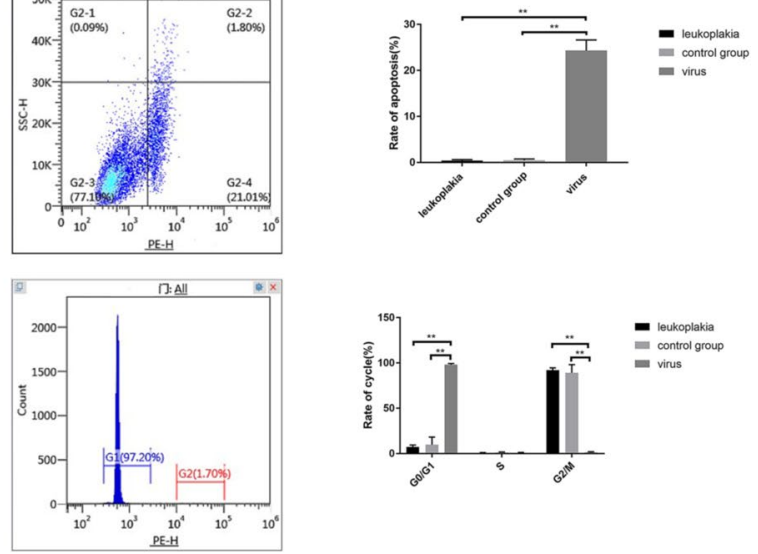

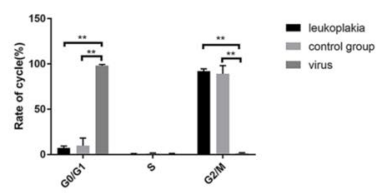

Fig. 4 Migration, proliferation, apoptosis, and cell-cycle distribution of HVCLCs after transfection with Glut-1 low-expressing lentivirus. a Transwell assay; b wound-healing assay; c CCK-8 assay; $\mathbf{d}$ apoptosis; e cell-cycle distribution

larynx, as in the stomach $[18,20,21]$. Also, we detected $\mathrm{H}+/ \mathrm{K}+-\mathrm{ATPase} \alpha, \beta$ expression in normal laryngeal tissues by RT-PCR, Western blotting, and IHC. The distribution and expression level of $\mathrm{H}+/ \mathrm{K}+-$ ATPase $\alpha$ did not differ significantly among the various laryngeal subregions. However, the expression level of the $\beta$-subunit was higher in the epiglottic cartilage based on Western blotting [19]. Laryngeal $\mathrm{H}+/ \mathrm{K}+$-ATPases may alter seromucinous secretion and regulate the acidic laryngeal microenvironment $[18,20$, 21]. Therefore, acid secreted by laryngeal $\mathrm{H}+/ \mathrm{K}+$ ATPases may reactivate pepsin absorbed in the laryngeal epithelium, leading to damage to the laryngeal mucosa, laryngitis, and tumorigenesis. In this study, exposure to pepsin-containing artificial gastric juice enhanced the invasive and migratory ability of HVCLCs and increased and decreased the proportions in the $\mathrm{S}$ and $\mathrm{G} 2 / \mathrm{M}$ phase and $\mathrm{G} 0 / \mathrm{G} 1$ phase, respectively. Therefore, pepsin is implicated in the development of VCL. After exposure to pepsin-containing artificial gastric juice, Glut- 1 and $\mathrm{H}+/ \mathrm{K}+$-ATPase $\alpha, \beta$ expression was correlated with the migration, proliferation, cell-cycle distribution, and apoptosis of HVCLCs. Also, inhibition of its expression indicated that Glut-1 regulates the expression 

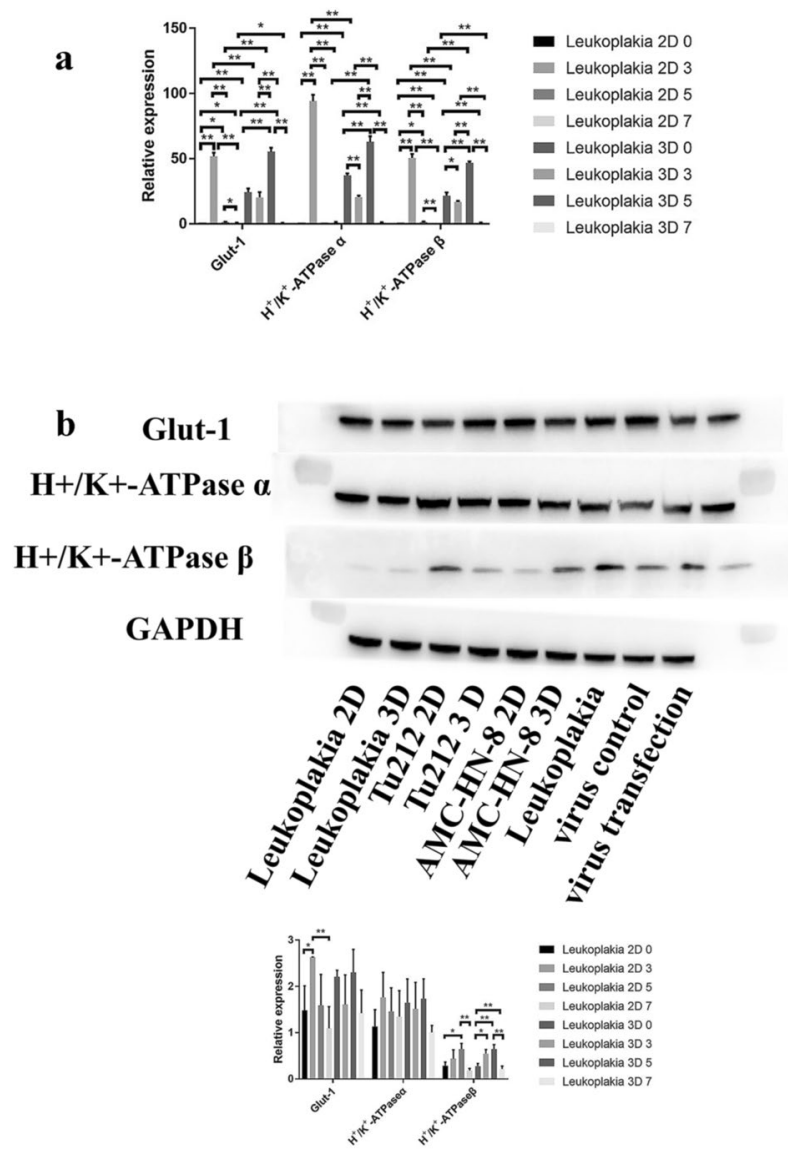

Fig. 5 Glut- 1 and $\mathrm{H}^{+} / \mathrm{K}^{+}$-ATPase $\alpha, \beta$ expression in $2 \mathrm{D}$ and $3 \mathrm{D}$ models of HVCLCs exposed to pepsin-containing artificial gastric juice by a RT-PCR and b Western blotting

of $\mathrm{H}+/ \mathrm{K}+-$ ATPase $\alpha, \beta$ in HVCLCs. Our findings indicate that pepsin plays a role in the development of VCL by increasing Glut-1 expression, causing elevated expression of $\mathrm{H}+/ \mathrm{K}+-$ ATPase $\alpha, \beta$ in HVCLCs. Pepsin damages the mitochondria of laryngeal epithelial cells, causing reprogramming of glucose metabolism [13, 16]. High expression of Glut-1 elevated glycolysis, leading to increased lactate, reducing the microenvironment $\mathrm{pH}$ and thus reactivating pepsin.

Also, Glut- 1 and $\mathrm{H}+/ \mathrm{K}+$-ATPase $\alpha, \beta$ expression in 30 laryngeal carcinoma adjacent tissues, 30 VCL tissues, and 30 laryngeal carcinoma tissues increased gradually $(p<0.05)$. Glut-1 expression was correlated with $\mathrm{H}+/ \mathrm{K}+$-ATPase $\alpha, \beta$ expression in HVCLCs. We reported previously that $\mathrm{H}+/ \mathrm{K}+-\mathrm{ATPase} \alpha, \beta$ expression increased in order in normal laryngeal tissues (30 specimens), paracarcinoma tissues (30 specimens), and laryngeal carcinoma tissues (30 specimens) by RT-PCR, Western blotting, and IHC. $\mathrm{H}+/ \mathrm{K}+$-ATPase $\alpha, \beta$ expression were significantly higher in laryngeal carcinoma than in paracarcinoma tissues. McCormick et al. reported that $\mathrm{H}+/ \mathrm{K}+-$ ATPase $\alpha$
(ATP4A) and $\beta$ (ATP4A) were expressed in laryngeal carcinoma tissues, paracarcinoma tissues, and laryngeal tissues from patients with LPR. However, there was no significant difference in expression, likely because of the small number of samples [16]. Therefore, $\mathrm{H}+/ \mathrm{K}+-\mathrm{ATPa}$ e is expressed in normal laryngeal tissues and is elevated during laryngeal epithelial hyperplasia and malignant transformation. However, the role of Glut 1 and $\mathrm{H}+/ \mathrm{K}+$-ATPase $\alpha, \beta$ expression in the pathogenesis of laryngeal carcinoma is unclear. Therefore, large prospective, multicenter studies are needed to clarify the mechanism of Glut-1-mediated $\mathrm{H}+/ \mathrm{K}+$-ATPase expression in laryngeal carcinogenesis, and the role of pepsin in this process.

This study had several limitations. First, we did not investigate the mechanism by which pepsin induces laryngeal malignant transformation. Second, the differences between 3D- and 2D-cultured cells should be explored. Finally, this was a retrospective study, and we did not apply the 24 MII$\mathrm{pH}$, reflux symptom index, or reflux finding score.

\section{Conclusions}

Pepsin-containing artificial gastric juice promoted the invasion and migration of HVCLCs. Pepsin-induced development of precancerous lesions is associated with abnormal expression of Glut- 1 and $\mathrm{H}^{+} / \mathrm{K}^{+}$-ATPase $\alpha, \beta$. The expression of Glut- 1 and $\mathrm{H}^{+} / \mathrm{K}^{+}$-ATPase $\alpha, \beta$ gradually increases from laryngeal precancerous lesions to laryngeal carcinoma. Therefore, Glut-1 may mediate the development of laryngeal precancerous lesions by upregulating $\mathrm{H}^{+} / \mathrm{K}^{+}$-ATPase expression, reactivating absorbed pepsin and damaging the laryngeal mucosa.

Supplementary Information The online version contains supplementary material available at https://doi.org/10.1007/s00405-021-07172-y.

Author contributions A YJ: conceptualization of the study and analysis of the data, wrote the manuscript. W TT: conceptualization of the study and support the funding. C ZZ: conceptualization of the study and analysis of the data; $\mathrm{Z} \mathrm{SH}$ : conceptualization of the study; analysis of the data, revision of the manuscript. B YY: analysis of the data, analysis of the data, S LF: collection of data, analysis of the data.

Funding This work was supported by Health Commission of Zhejiang Province, China (No. 2018KY051).

Availability of data and material Data are available on request to the authors.

Code availability Not applicable.

\section{Declarations}

Conflicts of interest The authors have no conflicts of interest to declare. 
Ethics approval All the procedures performed in the study were in accordance with the ethical standards of the institutions at which the study was conducted.

Consent to participate Informed consent was obtained from all individual participants included in the study.

Consent for publication Participants signed informed consent forms.

Open Access This article is licensed under a Creative Commons Attribution 4.0 International License, which permits use, sharing, adaptation, distribution and reproduction in any medium or format, as long as you give appropriate credit to the original author(s) and the source, provide a link to the Creative Commons licence, and indicate if changes were made. The images or other third party material in this article are included in the article's Creative Commons licence, unless indicated otherwise in a credit line to the material. If material is not included in the article's Creative Commons licence and your intended use is not permitted by statutory regulation or exceeds the permitted use, you will need to obtain permission directly from the copyright holder. To view a copy of this licence, visit http://creativecommons.org/licenses/by/4.0/.

\section{References}

1. Chen YL, Bao YY, Zhou SH, Yao HT, Chen Z (2021) Relationship between pepsin expression and dysplasia grade in patients with vocal cord leukoplakia. Otolaryngol Head Neck Surg 164(1):160-165. https://doi.org/10.1177/0194599820938654

2. Lee DH, Yoon TM, Lee JK, Lim SC (2015) Predictive factors of recurrence and malignant transformation in vocal cord leukoplakia. Eur Arch Otorhinolaryngol 272(7):1719-2124. https://doi. org/10.1007/s00405-015-3587-8

3. Kostev K, Jacob LEC, Kalder M, Sesterhenn AM, Seidel DU (2018) Association of laryngeal 7cancer with vocal cord leukoplakia and associated risk factors in 1,184 patients diagnosed in otorhinolaryngology practices in Germany. Mol Clin Oncol 8(5):689-693. https://doi.org/10.3892/mco.2018.1592

4. Lu G, Ding X, Xu W (2021) Association between laryngopharyngeal reflux and vocal fold leukoplakia. ORL J Otorhinolaryngol Relat Spec 83:159-166. https://doi.org/10.1159/000512527

5. Anis MM, Razavi MM, Xiao X, Soliman AMS (2018) Association of gastroesophageal reflux disease and laryngeal cancer. World J Otorhinolaryngol Head Neck Surg 4(4):278-281. https://doi.org/ 10.1016/j.wjorl.2017.12.011

6. Pearson JP, Parikh S, Orlando RC, Johnston N, Allen J, Tinling SP, Johnston N, Belafsky P, Arevalo LF, Sharma N, Castell DO, Fox M, Harding SM, Morice AH, Watson MG, Shields MD, Bateman N, McCallion WA, van Wijk MP, Wenzl TG, Karkos PD, Belafsky PC (2001) Review article: reflux and its consequencesthe laryngeal, pulmonary and oesophageal manifestations. Conference held in conjunction withthe 9th International Symposium on Human Pepsin (ISHP) Kingston-upon-Hull, UK,21-23 April 2010. Aliment Pharmacol Ther 33(Suppl 1):1-71. https://doi.org/ 10.1111/j.1365-2036.2011.04581.x

7. Johnston N, Dettmar PW, Lively MO, Postma GN, Belafsky PC, Birchall M, Koufman JA (2006) Effect of pepsin on laryngeal stress protein (Sep70, Sep53, and Hsp70) response: role in laryngopharyngeal reflux disease. Ann Otol Rhinol Laryngol 115(1):47-58. https://doi.org/10.1177/000348940611500108

8. Johnston N, Wells CW, Samuels TL, Blumin JH (2010) Rationale for targeting pepsin in the treatment of reflux disease. Ann Otol
Rhinol Laryngol 119(8):547-558. https://doi.org/10.1177/00034 8941011900808

9. Johnston N, Wells CW, Blumin JH, Toohill RJ, Merati AL (2007) Receptor-mediated uptake of pepsin by laryngeal epithelial cells. Ann Otol Rhinol Laryngol 116(12):934-938. https://doi.org/10. 1177/000348940711601211

10. Yin CY, Zhang SS, Zhong JT, Zhou SH (2021) Pepsin and laryngeal and hypopharyngeal carcinomas. Clin Exp Otorhinolaryngol 14(2):159-168. https://doi.org/10.21053/ceo.2020.00465

11. McCann AJ, Samuels TL, Blumin JH, Johnston N (2020) The role of pepsin in epithelia-mesenchymal transition in idiopathic subglottic stenosis. Laryngoscope 130(1):154-158. https://doi. org/10.1002/lary.27879

12. Tan JJ, Wang L, Mo TT, Wang J, Wang MG, Li XP (2019) Pepsin promotes il-8 signaling-induced epithelial-mesenchymal transition in laryngeal carcinoma. Cancer Cell Int 19:64-77. https://doi.org/ 10.1186/s12935-019-0772-7

13. Samuels TL, Pearson AC, Wells CW, Stoner GD, Johnston N (2013) Curcumin and anthocyanin inhibit pepsin-mediated cell damage and carcinogenic changes in airway epithelial cells. Ann Otol Rhinol Laryngol 122(10):632-641

14. Dai YF, Tan JJ, Deng CQ, Liu X, Lv ZH, Li XP (2020) Association of pepsin and DNA damage in laryngopharyngeal refluxrelated vocal fold polyps. Am J Otolaryngol 41(6):102681. https:// doi.org/10.1016/j.amjoto.2020.102681

15. Samuels TL, Handler E, Syring ML, Pajewski NM, Blumin JH, Kerschner JE, Johnston N (2008) Mucin gene expression in human laryngeal epithelia: effect of laryngopharyngeal reflux. Ann Otol Rhinol Laryngol 117(9):688-695. https://doi.org/10.1177/00034 8940811700911

16. McCormick CA, Samuels TL, Battle MA, Frolkis T, Blumin JH, Bock JM, Wells C, Yan K, Altman KW, Johnston N (2021) H+/ $\mathrm{K}+\mathrm{ATPase}$ expression in the larynx of laryngopharyngeal reflux and laryngeal cancer patients. Laryngoscope 131(1):130-135. https://doi.org/10.1002/lary.28643

17. Stevanović S, Radić R, Kačarević ŽP, Bedeković V, Aras I, Baudoin T, Šoš D, Vrselja Z, Ivkić M (2015) Proton pump (H+/ $\mathrm{K}+$-ATPase) expression in human larynx. Auris Nasus Larynx 42(6):458-462. https://doi.org/10.1016/j.anl.2015.04.013

18. Altman KW, Kinoshita Y, Tan M, Burstein D, Radosevich JA (2011) Western blot confirmation of the $\mathrm{H}+/ \mathrm{K}+$-ATPase proton pump in the human larynx and submandibular gland. Otolaryngol Head Neck Surg 145(5):783-788. https://doi.org/10.1177/01945 99811415589

19. Bao YY, Jiang Q, Li ZW, Yu E, Zhou SH, Yao HT, Fan J, Yong WW (2020) Gastric $\mathrm{H}^{+} / \mathrm{K}^{+}$-ATPase expression in normal laryngeal tissue and laryngeal carcinoma. Onco Targets Ther 13:12919-12931. https://doi.org/10.2147/OTT.S276233

20. Altman KW, Waltonen JD, Hammer ND, Radosevich JA, Haines GK 3rd (2005) Proton pump (H+/K+-ATPase) expression in human laryngeal seromucinous glands. Otolaryngol Head Neck Surg 133(5):718-724. https://doi.org/10.1016/j.otohns.2005.07. 036

21. Altman KW, Haines GK 3rd, Hammer ND, Radosevich JA (2003) The $\mathrm{H}+/ \mathrm{K}+-A T P a s e$ (proton) pump is expressed in human laryngeal submucosal glands. Laryngoscope 113(11):1927-1930. https://doi.org/10.1097/00005537-200311000-00013

22. Zhang Z, Bao YY, Zhou SH (2020) Pump proton and laryngeal $\mathrm{H}^{+} / \mathrm{K}^{+}$- ATPases. Int J Gen Med 13:1509-1514. https://doi.org/ 10.2147/IJGM.S284952

23. Scudieri P, Musante I, Caci E, Venturini A, Morelli P, Walter C, Tosi D, Palleschi A, Martin-Vasallo P, Sermet-Gaudelus I, Planelles G, Crambert G, Galietta LJ (2018) Increased expression of ATP12A proton pump in cystic fibrosis airways. JCI Insight 3(20):e123616. https://doi.org/10.1172/jci.insight.123616 
24. Liu W, Zhao ZM, Liu YL, Pan HF, Lin LZ (2019) Weipiling ameliorates gastric precancerous lesions in Atp $4 \mathrm{a}^{\top} /$ mice. BMC Complement Altern Med 19(1):318. https://doi.org/10.1186/ s12906-019-2718-y

25. Liu W, Pan HF, Yang LJ, Zhao ZM, Yuan DS, Liu YL, Lin LZ (2020) Panax ginseng C. A. Meyer (Rg3) ameliorates gastric precancerous lesions in Atp4a-/- Mice via inhibition of glycolysis through PI3K/AKT/miRNA-21pathway. Evid Based Complem Alternat Med. https://doi.org/10.1155/2020/2672648

26. Dai LB, Yu Q, Zhou SH, Bao YY, Zhong JT, Shen LF, Lu ZJ, Fan J, Huang YP (2020) Effect of combination of curcumin and GLUT-1 AS-ODN on radiosensitivity of laryngeal carcinoma through regulating autophagy. Head Neck 42(9):2287-2297. https://doi.org/10.1002/hed.26180

27. Zhou SH, Fan J, Chen XM, Cheng KJ, Wang SQ (2009) Inhibition of cell proliferation and glucose uptake in human laryngeal carcinoma cells by antisense oligonucleotides against glucose transporter-1. Head Neck 31(12):1624-1633. https://doi.org/10. 1002/hed.21137

28. Lu ZJ, Yu Q, Zhou SH, Fan J, Shen LF, Bao YY, Wu TT, Zhou ML, Huang YP (2019) Construction of a GLUT-1 and HIF-1 $\alpha$ gene knockout cell model in HEp-2 cells using the CRISPR/Cas9 technique. Cancer Manag Res 11:2087-2096. https://doi.org/10. 2147/CMAR.S183859
29. Němejcová K, Rosmusová J, Bártů M, Důra M, Tichá I, Dundr P (2017) Expression of Glut-1 in normal endometrium and endometrial lesions: analysis of 336 cases. Int J Surg Pathol 25(5):389_ 396. https://doi.org/10.1177/1066896916683510

30. Legan M, Tevžič S, Tolar A, Luzar B, Marolt VF (2011) Glucose transporter-1 (GLUT-1) immunoreactivity in benign, premalignant and malignant lesions of the gallbladder. Pathol Oncol Res 17(1):61-66. https://doi.org/10.1007/s12253-010-9281-7

31. Brands RC, Köhler O, Rauthe S, Hartmann S, Ebhardt H, Seher A, Linz C, Kübler AC, Müller-Richter UDA (2017) The prognostic value of GLUT-1 staining in the detection of malignant transformation in oral mucosa. Clin Oral Investig 21:1631-1637. https:// doi.org/10.1007/s00784-016-1954-5

32. Pereira KM, Feitosa SG, Lima AT, Luna EC, Cavalcante RB, de Lima KC, Chaves FN, Costa FW (2016) Immunohistochemical evaluation of glucose transporter type 1 in epithelial dysplasia and oral squamous cell carcinoma. Asian Pac J Cancer Prev 17(1):147-151. https://doi.org/10.7314/apjcp.2016.17.1.147

Publisher's Note Springer Nature remains neutral with regard to jurisdictional claims in published maps and institutional affiliations. 